doi:10.5128/ERYa13.10

\title{
KREEKA NIMED EESTIKEELSES TEKSTIS JA KÕNES
}

\section{Kaarina Rein}

Ülevaade. Kreeka ja teiste mitte-ladina alfabeedis nimede kirjutamise teemal on Eestis korduvalt arutletud ning kehtestatud on ka reeglid, millest juhinduda. Praktikas ei ole nende reeglite kasutamine alati lihtne, eelkõige sellepärast et nime algkuju ei pruugita teada. Kreeka nimed jõuavad tänapäeval eestikeelsesse teksti enamasti teiste keelte vahendusel ning seega jõuavad eestikeelsesse kirjapilti ja hääldusse teiste keelte traditsioonid ning transkriptsiooni- ja hääldusreeglid. Kõige suuremaks mõjutajaks on nüüdsel ajal inglise keel.

Vanakreeka, Uue Testamendi, bütsantsi ning uuskreeka nimede edasiandmisel on eesti keeles olnud erinevad tavad ja praktika ning tänapäevalgi tanskribeeritakse neid erinevalt. Nende vahede tajumine võib olla keeruline ning kindlasti tekib ka küsitavusi, kas juhinduda ühtedest või teistest reeglitest. Artikkel annab ülevaate erinevate kreeka nimede kasutamisest eesti keeles ning juhib tähelepanu probleemidele.*

Võtmesõnad: kreeka nimed, vanakreeka nimed, uuskreeka nimed, onomastika, keelekontaktid

\section{Sissejuhatus}

Aegade jooksul on kreeka nimesid eesti keeles kirjutatud mitmel moel. Peeter Päll (2005) on oma doktoritöös "Võõrnimed eestikeelses tekstis" kreeka nimede ümberkirjutuses eristanud kolme võimalust: 1) piiblinimed; 2) vanakreeka nimed; 3) uuskreeka nimed (Päll 2005: 76). Ühtlasi annab ta ajaloolise ülevaate nende nimede latinisatsioonist ning vaidlustest, mis on toimunud nende kasutamisel eestikeelses tekstis (Päll 2005: 76-81). Nüüdseks on eesti keeles kohaldatud eraldi reeglid vanakreeka ja uuskreeka nimede kirjutamiseks ning nende korrektseks edastamiseks on kasutusel kaks tabelit, mis esmakordselt ilmusid 1999. aasta õigekeelsussõnaraamatus (ÕS 1999: 1025-1027). Samad juhised on ära toodud ka

* Artikkel on valminud Rootsi Teadusnõukogu (Vetenskapsrådet) projekti nr 2016-01881 “Helleno-Nordica: 
Eesti Keele Instituudi kodulehel ${ }^{1}$ ja P. Pälli raamatus "Maailma kohanimed" (Päll 2005: 596-598) ning ka 2013. a ilmunud õigekeelsussõnaraamatus. Seega on teoreetiline alus nii vana- kui uuskreeka nimede kirjutamiseks eesti keeles olemas. Ent tegelikkuses ei ole alati selge, kus tõmmata piir erinevate kreeka nimede vahel, milliste reeglite järgi ikkagi nimesid kirja panna ja kuidas neid hälddada. Tänapäeva Kreekas kasutatakse ka vanakreeka nimesid ning vahel võib range jaotus vana ja uue ning mugandatud vormi vahel olla keeruline, nagu on väga õigesti märkinud ka P. Päll (1998: 413). Küsimusi tekib näiteks bütsantsi nimede kajastamisega - kas neile peaksid kehtima vana- või uuskreeka transkriptsiooni reeglid.

Paraku ei jõua kreeka nimed tänapäeval eesti keelde sugugi mitte algkeelest, vaid teiste keelte - eriti inglise keele - vahendusel, mis komplitseerib nende kasutamist veelgi. Kasutamise all mõeldakse siinkohal nii kirjalikku teksti kui suulist kõnet, sest kuigi kirjapanekul võib kehtida põhimõte epistula non erubescit, ilmnevad probleemid just suulises kõnes.

Artikkel tõukub vajadusest kasutada eesti keeles nii kirjalikult kui suuliselt kreeka nimesid ning annab lühiülevaate, kuidas ja millest lähtuvalt on kreeka nimed 20. sajandi lõpu ja 21. sajandi eestikeelsetes tekstides vormistatud, valgustades probleemseid kohti nii kreeka nimede kirjutamisel kui ka hääldamisel. Vaadeldakse kreeka nimede kasutamist kultuuriloolistes ja kirjanduslikes tekstides, firmade ja teadusväljaannete nimedes ning ajakirjanduses. Suulise kasutuse tähelepanekud on tehtud eelkõige ERR-i Klassikaraadio saadete põhjal.

\section{Vanakreeka nimed}

Vanakreeka nimede kirjutamise üle eesti keeles on arutletud ligi 100 aastat (Päll 2005: 77). 1976. aasta ÕS-is on antud nende kirjutamiseks kaks võimalust, millest üks on eestipärane, teine aga kasutab võõrtähti $x, y$ ning konsonantüheneid $c h, p h$, $r h$, th ja märgib sõnaalguse spiritus asper'it $h$-tähega (ÕS 1976: 900-902). Teist süsteemi soovitatakse kasutada tänapäevalgi ning see vanakreeka-ladina tähetabel on ära toodud Eesti Keele instituudi kodulehel ja õigekeelsussõnaraamatutes (ÕS 1999: 1025-1026, ÕS 2013: 1204-1206).

Tabel 1. Vanakreeka-ladina tähetabel (ÕS 2013: 1204-1206)

\begin{tabular}{|c|c|c|c|}
\hline $\mathrm{Aa}$ & $=\mathrm{a}$ & $\mathrm{M \mu}$ & $=\mathrm{m}$ \\
\hline al & $=\mathrm{a}$ (kohanime lõpus) & $\mathrm{Nv}$ & $=\mathrm{n}$ \\
\hline au & $=\mathrm{au}$ & $\equiv \xi$ & $=x$ \\
\hline$B \beta$ & $=\mathrm{b}$ & Oo & $=0$ \\
\hline$\Gamma \gamma$ & $=\mathrm{g}$ & Ol & $=\mathrm{i}$ (kohanime lõpus) \\
\hline$\gamma Y$ & $=\mathrm{ng}$ & ou & $=\mathrm{u}$ \\
\hline үK & $=\mathrm{nk}$ & $\Pi \pi$ & $=p$ \\
\hline$\gamma \xi$ & $=\mathrm{nx}$ & $P \rho$ & $=r$ \\
\hline$\gamma X$ & $=\mathrm{nch}$ & $\dot{\rho}$ & $=\mathrm{rh}$ \\
\hline$\Delta \delta$ & $=d$ & $\Sigma \sigma \varsigma$ & $=\mathrm{s}$ \\
\hline $\mathrm{E \varepsilon}$ & $=\mathrm{e}$ & $\mathrm{T \tau}$ & $=\mathrm{t}$ \\
\hline$\varepsilon U$ & $=\mathrm{eu}$ & $\gamma u$ & $=y$ \\
\hline
\end{tabular}




\begin{tabular}{|l|l|l|l|}
\hline$Z \zeta$ & $=Z$ & $\Phi \varphi$ & $=\mathrm{ph}$ \\
\hline $\mathrm{H} \eta$ & $=\mathrm{e}$ & $\mathrm{XX}$ & $=\mathrm{ch}$ \\
\hline$\Theta \theta$ & $=\mathrm{th}$ & $\Psi \Psi$ & $=\mathrm{ps}$ \\
\hline $\mathrm{II}$ & $=\mathrm{i}$ & $\Omega \omega$ & $=0$ \\
\hline $\mathrm{KK}$ & $=\mathrm{k}$ & $\cdot$ & $=\mathrm{h}$ (vokaali ees) \\
\hline$\Lambda \lambda$ & $=\mathrm{I}$ & & \\
\hline
\end{tabular}

Lisaks transkriptsiooni reeglitest lähtumisele saab vanakreeka nimede õigekirja järele vaadata teatmeteostest. Siiani on kõige autoriteetsem eestikeelne raamat, kus vanakreeka nimede õige kirjapilt kajastub, olnud 1983. ja 1985. aastal ilmunud “Antiigileksikon”. Seal on ka nimede rõhk punktiga märgitud, näiteks Aristotẹles, Aspasịa, Herạkleitos, Pythẹas. ${ }^{2}$ Nimede kirjutamisel on “Antiigileksikonis" lähtutud mõlemast ÕS 1976-s soovitatud süsteemist - seega kirjutatakse Homerosele omistatud eepose kangelase nime Odysseus, ent tema seiklustest jutustav kirjandusteos on kirjapildis Odüsseia. Samuti kirjutatakse eestipärasemalt mitmed tuntud linnanimed, näiteks Smürna ja Aleksandria, ning leidub ka mugandatud traditsioonilisi nimekujusid, näiteks maakonnad Lakoonika, Arkaadia, Boiootia. Vanakreeka nimede kirjutamisel võib seega valida, kas teha seda täpselt transkriptsioonireeglite järgi või lähtuda "Antiigileksikonist”. Esimene variant on kindlasti vaevarikkam, sest erinevate alfabeetide tähed tuleb vastavusse viia, teisest allikast on õige nimekuju leidmine märksa lihtsam, sest õige variant on juba antud. Tuleb lisada, et vanakreeka luuletekstides esineb erinevaid nimekujusid rohkem, kui neid on "Antiigileksikonis" pakutud, sest vanakreeka luulekeelt iseloomustab vormivabadus ning seega ei õigusta ortograafiareeglite range järgimine ennast ka eestikeelsetes tõlgetes (Päll 2006: 11).

Kuna latiniseerimisel antakse vanakreeka nimesid eesti keeles edasi häälduspäraselt, siis ei teki eesti keelt emakeelena rääkijatel nende kirjutamisel ega ka hääldamisel suuremaid vigu. Probleemidena võib välja tuua muude keelte mõju, eriti anglitsismide sissetungi ning raskused aspireeritud häälikute ning rõhureeglitega. Eestikeelsesse kirjapilti tungivate inglise ja teistele keeltele omaste nimekujude näitena võib mainida nimekasutusi Galen pro Galenos, Zephyr pro Zephyros. Mütoloogiast tuntud võidujumalanna Nike nimi võib seostuda eelkõige spordiriideid tootva ettevõttega ning seetõttu ka vastavalt häälduda (Rein 2004: 13).

Kreeka keeles leidub tähti ja häälikuid, millel eesti keeles vasted puuduvad, ning selliste aabete edasiandmisel eesti keeles on olnud eri lahendused. Nii on kreeka aspireeritud häälikute $\theta$ (teeta), $\varphi$ (fii) ja $\chi$ (hii) hääldamisel ning kirjutamisel eesti keeles olnud ebajärjekindlust ning ka liialdamisi. Kreeka $\chi$-d edasi andev kombi-

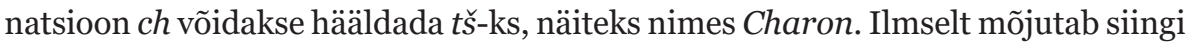
hääldust inglise keel. Kehtiva tabeli järgi tuleks kreeka täht $\theta$ edasi anda th-na, $\varphi$ aga ph-na. Enamasti seda nii ka tehakse, kuid näiteks nimed Kó $\rho$ v $\theta o \varsigma, M \alpha \rho \alpha \theta \omega ́ v$ ja $\Delta \varepsilon \lambda \varphi o i$ antakse eesti keeles edasi tavaliselt kujul Korintos, Maraton ja Delfi (mitte Korinthos, Marathon ja Delphi), seega kahes esimeses nimes $t$-tähe järele $h$-d ei lisata ning Delfi ei kirjutata mitte $p h$-ga vaid $f$-ga, nii nagu näeb ette 1976. a õigekeelsussõnaraamatu 1. versioon (ÕS 1976: 901). Mainitud nimede eestipärasemaks kujunenud versioone kajastab ka “Antiigileksikon”. Ent taolistes küsimustes

2 Rõhu kajastamise põhimõtted on "Antiigileksikonis" esitatud järgmiselt: rõhk on märgitud punktiga rõhulise silbi täishääliku või punkti ja kaarekesega kaksiktäishääliku all. Kui on antud ka rõhulise silbi hääldus, siis on rõhk märgitud ainult seal. Rõhk on jäetud märkimata, kui see langeb esimesele silbile või kui rõhulise silbi vokaal kirjutatakse kahekordselt. Esimesel silbil olevat rõhku on märgitud ainult siis, kui järgsilbis on pikk vokaal, kuid esimese silbi vokaal on lühike. Kui pikk vokaal on nii esimeses kui ka järgsilbis, siis rõhku ei ole märgitud (Antiigileksikon 1983: 6). 
on ka vastupidiseid näiteid, eesti keeles kiputakse kreeka nimede edasiandmisel $t$-d aspireerima ning $h$-tähte lisama sinna, kus seda tegelikult vaja ei ole, s.o kus kreeka keeles ei ole mitte täht $\theta$ (teeta), vaid $\tau$ (tau). Näited siinkohal on mütoloogiliste tegelaste nimed Artemis ja Metis, mis Eestis on vahel kasutusele võetud kujul Arthemis ja Methis. ${ }^{3}$ Võimalik, et $h$ lisamisel loodetakse nime "kreekapärasemaks" muuta.

Kreeka keele rõhureeglid on eestlastele tihti rasked, ent vanakreeka nimede transkribeerimisel rõhku neile siiski ei märgita. Klassikalise tragöödiakirjanike

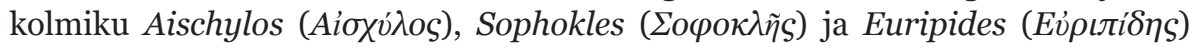
nimedes tekitab esimeses ja viimases rõhk segadust ning nimes Sophokles rõhutatakse esimest silpi, kuigi kreeka keeles paikneb rõhk lõpus. Kindlasti ongi eesti keelele nime lõpus paiknev rõhk võoras - lisaks Sophoklese nimele iseloomustab

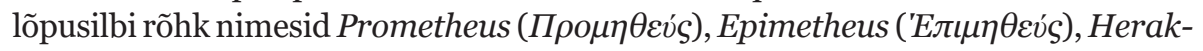

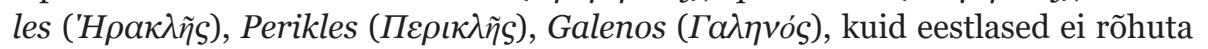
nende viimast, vaid tavaliselt hoopis esimest silpi.

Eksitav võib olla vanakreeka nimede nii kreeka- kui ka ladinapärase rõhu olemasolu, seega eksisteerivad erinevate rõhkudega variandid näiteks nimedel Aristoteles, Demokritos ja Demosthenes jt, mis võivad omakorda segadust põhjustada. Eesti keeles on nüüdseks minetatud vanakreeka nimede kreeka ja ladina paralleelvariandid, ${ }^{4}$ mis on siiani probleemiks läti keeles (vt Rein 2016: 571). Seega kirjutame eesti keeles kreekapäraselt Aischylos, mitte ladinapäraselt Aeschylus. Ladinapäraseid nimelõppe võib siiski ette tulla Piibli nimedes, mida käsitletakse järgmises peatükis.

Kokkuvõtvalt võib öelda, et vanakreeka nimed tekitavad eesti keeles ilmselt kõige rohkem raskusi just suulises kõnes, kui on vaja nime rõhu asukohta määrata. Kirjutamisel (ehkki ka hääldamisel) on ebajärjekindlust aspireeritud häälikute edasiandmises. Vanakreeka nimede edasiandmise traditsioonid eesti keeles väärivad põhjalikumat uurimust.

\section{Kreeka nimed Uues Testamendis}

Uue Testamendi nimed on kreeka nimedest kindlasti kõige enam eesti keeles kasutamist ja käsitlemist leidnud, enamasti on tegemist mugandatud vormidega, millel on välja kujunenud eestipärane transkriptsioon. Kuna Uue Testamendi nimesid on pidevalt vaja suuliselt kasutada, peavad nad olema hõlpsasti hääldatavad ja eesti keelele omased. Nende kohta on eesti keeles ilmunud ka mitu käsiraamatut, vt Lilleväli (2000) ja Palli (2016).

Uue Testamendi nimesid on eestipärastatud suupärasesse kohta topelttäishääliku kirjutamise ja aspiratsiooni kaotamise teel. Siinkohal mõni näide geograafiast: nimed, mis "Antiigileksikonis" on antud kujul Thessalonịe, Mytilene, Samothrake, kajastuvad Uues Testamendis kujul Tessaloonika, Mitüleene, Samotraake. Võib täheldada, et mugandatud vormi rõhk võib kreekapärasest rõhust erinev olla, ning lisaks kohanimedele kehtib see ka isikunimedes, näiteks Jaakobus

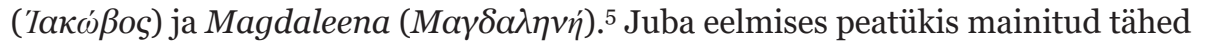

\footnotetext{
3 Näidetena võib siin välja tuua ettevõtte Arthemise Kontoritarbed ning humanitaarteaduste ajakirja Methis nime. Ehkki viimase kodulehel on öeldud, et nimi Methis ei tähenda midagi ning on inspireeritud tarkusejumalanna Metise nimest, seostub see siiski genitiivi vormiga kreekakeelsest sõnast $\dot{\eta} \mu \varepsilon \dot{\theta} \theta \eta$ 'joove'.

4 "Antiigileksikoni" ilmumise ajal oli see teema veel aktuaalne, kuid seal võeti suund märksõnade originaalkujul kajastamisele (Antiigileksikon 1983: 6).

5 Selle peatüki nimede näited on võetud Toomas Pauli ja Uku Masingu Uue Testamendi tõlkest (Uus Testament ja psalmid 1990) ning piiblitõlke veebiportaalist Piibel.net. Kõik näidetes toodud nimed ei pruugi etümoloogiliselt olla kreeka päritolu, siinkohal lähtutakse nende kasutamisest kreekakeelses piiblitekstis.
} 
$\theta$ ja $\varphi$ antakse eestikeelses Uues Testamendis edasi $t$ ja $f$-ina: näiteks nimedes Korintos, Efesos, Filip(p)i, nii nagu on pakutud 1976. aastal ilmunud õigekeelsussõnaraamatu esimeses süsteemis (ÕS 1976: 901).

Millisel määral on eestikeelse Uue Testamendi nimevariantide kujunemist ajaloo jooksul mõjutanud teised keeled, vajab eraldi uurimist. Uue Testamendi isikunimede edasiandmisel esineb juba Reuchlini häl̈lduse mõju, ${ }^{6}$ näiteks nimed Sebedeus ja Matteus peaksid tegelikult translitereeruma kujul Zebedaios ja Matthaios. Seega diftongi $\alpha \iota$ antakse neis edasi $e$-na, mitte ai-na.

Eelmise lõigu näidetes võis lisaks vokaalimuutustele näha ka ladinapärast lõppsilpi -us, mida on nende nimede eestikeelses traditsioonis kasutatud. Samasuguse ladinapärase lõpuga on Piiblis näiteks veel mehenimed Peetrus, Paulus ja Markus. Käsiraamatud võivad Uue Testamendi nimede lõppude kohta erinevat informatsiooni anda. Nii kajastub nimi Stefanos "Piibli nimede leksikonis" (Lilleväli 2000: 220) ja portaalis Piibel.net ${ }^{7}$ kreekapärase lõpuga, ent raamatus "Õigeusu nimi” esineb ta ladinapärase lópuga Stefanus (Palli 2016: 125-126). Ladinapärase versiooni eelistamine kreeka nime puhul eeldanuks selgitust, sest eestikeelses Uues Testamendis on kasutusel kreekapärane variant (Uus Testament ja psalmid 1990: 675). Lisaks kasutamisele Piiblis kannab eelmainitud nime ka ametisolev Eesti Apostliku-Õigeusu Kiriku metropoliit Stefanus, kelle nimi on samuti kasutusse läinud ladinapärase lõpuga.

Ülaltoodust nähtub, et Uue Testamendi nimesid on teiste kreeka nimedega võrreldes kõige enam eesti keelde mugandatud, sest neid on pidevalt vaja suuliselt kasutada.

\section{Bütsantsi nimed}

Bütsantsi nimesid on eesti keeles tavaliselt kajastatud vanakreeka transkriptsiooni

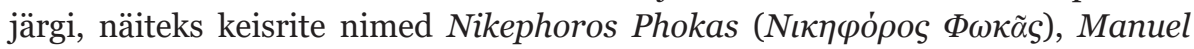

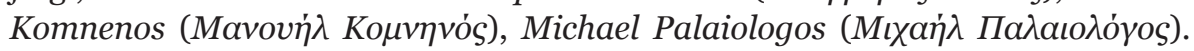
Rõhku transkribeeritud bütsantsi nimedel ei märgita.

Tegelikkuses oli bütsantsi nimede kasutamise ajal juba kasutusel Reuchlini hääldus, mis aeg-ajalt mõjutab nimede kirjutusviisi, näiteks nimes Irene (kr Ei̊ ka eelmises lõigus toodud keisridünastia nime võib kohata kujul Paleologos. Samuti mõjutavad bütsantsi nimede kajastamist aeg-ajalt uuskreeka nimede transkriptsiooni reeglid. Kui vanakreeka nimedes antakse kreeka diftongi ov edasi $u$-na, siis bütsantsi nimedes esitatakse see vahel ka ou-na, näiteks kunstniku El Greco kreeka

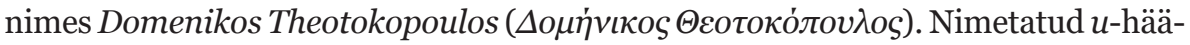
liku kajastamise varianti on eelistatud ka eesti keelde tõlgitud Gugliemo Cavallo raamatus "Bütsantsi inimene", kus võib leida näiteks nime Michael Kerouliarios (1992: 354), tavapärase vanakreeka transkriptsiooni järgi peaks see perekonnanimi esinema kujul Keruliarios. Mugandatud kreeka nimedest on Bütsantsist rääkivates

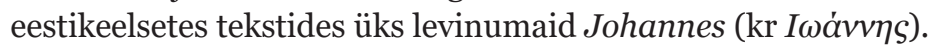

\footnotetext{
6 Arvatavasti delabialiseerus osa vanakreeka vokaale ja vokaalühendeid juba hellenismiaja algul ja muutus kõrgeteks eesvokaalideks, hakates häälduma $i$-häälikuna, nagu täht $ı$ (ioota). Sellest mõjutatud vokaalid olid $\eta, v$ ning diftongid $\varepsilon l$, o ja $v ı$, mis hakkasid häälduma ühtemoodi. Kahte erinevat hääldusversiooni (vana- ja uuskreeka oma) hakati nimetama tähe $\eta$ hääldamise järgi vastavalt eetatsismiks ja iitatsismiks. Lisaks hakati hilisemas kreeka keeles diftongi aı hääldama lühikese $e$-na, samamoodi nagu tähte $\varepsilon$. Seega ongi eestikeelsetes nimevariantides e seal, kus kreeka keeles on täishäälikuühend al. Sellist hääldust on hakatud nimetama Saksa humanisti Johann Reuchlini (1455-1522) järgi vastandina kunstlikult taastatud Erasmuse hääldusele. Täpsemalt vt kreeka keele häälduse muutumise kohta nt http://www.biblicalgreek.org/links/pronunciation.php\#History 7 http://piibel.net/\#q=stefanos
} 
Reuchlini hääldus tungib bütsantsi nimedes sisse ka kreekakeelsete ühendite $\gamma \iota, \gamma \varepsilon \iota, \gamma \eta, \gamma o \iota, \gamma v$ edasiandmisel. Vanakreeka keeles vastavad neile enam-vähem üksüheselt ühendid gi, gei, ge, goi, gy ning nii neid ka translitereeritakse, ent uuskreeka keeles märgib selline ühend $j(i)$-häälikut. Kristlikul ajal nimedes rohkesti

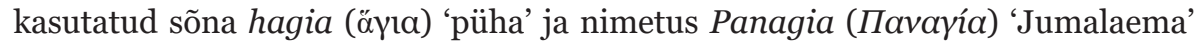
hääldusid juba Bütsantsi ajal vastavalt aj(i)a ja Panaj(i)a. Inglise keel mõjutab siingi: kuna j vasteks seal on hoopis $y$, kirjutatakse neid sõnu kujul ayia ja Panayia ning sellisel kujul on nad ka eestikeelsetesse tekstidesse jõudnud. Näiteks võib siin tuua Jaan Kaplinski raamatu "Santorini. Teekond Ayia Triadasse", kus esimesena mainitud nimekomponent esineb isegi pealkirjas ning samuti kajastub seal nimekuju Panayia (Kaplinski 2011: 46, 273-274, 276-278). Selles raamatus esineb ka Kreeta linnanimi kujul Ayios Nikolaos (Kaplinski 2011:163), ent samas võib sealt leida eestipärasema kujuga Ateena tänavanime Ajiou Konstandinou (Kaplinski 2011: 123).

Inglise keelest kipub bütsantsi nimedesse $k$ asemele tungima ka $c$-täht, näiteks nimes Johannes Scylitzes (Vseviov 2004: 522), kus perekonnanimi peaks reeglite järgi olema kujul Skylitzes.

Eraldi on bütsantsi nimede kirjutamise teemale tähelepanu pööratud eesti keelde tõlgitud raamatus "Bütsants. Impeeriumi ajalugu", kus nende kasutusviisi kohta on toodud märkus: üldtuntud nimed on toodud nende käibel oleval kujul (Theodoros, Johannes, Thessalonike, Konstantinoopol), kõigi teiste nimede puhul on esitatud nende kreekakeelse kuju transkriptsioon, vältides võimaluse korral nende ladinapäraseid kujusid: näiteks Prokopios, mitte Procopius, ja Nikephoros, mitte Nicephorus jne (Stathakopoulos 2016: 15).

Kokkuvõtvalt võib öelda, et eesti keeles kirjutatakse bütsantsi nimesid vanakreeka transkriptsiooni reeglite järgi, ent vahel tungib sellesse nimekirjutusse uuskreeka transkriptsiooni elemente ning ka inglise keele mõjutusi. Võrreldes vanakreeka nimedega on bütsantsi nimed tihti pikemad ning vajaksid esimestest enamgi juhiseid rõhu paiknemise kohta.

\section{Uuskreeka nimed}

Uuskreeka nimedest eesti keeles on küll juba mitmel korral eraldi kirjutatud (vt Kurtna 1966, Rein 2002, Päll 2005), kuid pärast nende kirjutiste ilmumist on kreeka nimede kajastumises eestikeelsetes tekstides nii mõndagi muutunud. Väidetavalt sai uuskreeka nimede kirjutamine eesti tekstides alguse uuskreeka kirjanduse tõlkimisest eesti keelde (Kurtna 1966: 51). Lisaks üksikutele kreeklaste mainimistele ajakirjanduses, oligi ilukirjandus 20. sajandil põhiline koht, kus uuskreeka nimesid võis eesti keeles kohata. Sellest ajendatuna on täienduseks ametlikele uuskreeka nimede transkribeerimise reeglitele (ISO 8431997 TL, Päll 1993) välja pakutud ka häälduspärasem variant nende kirjutamiseks, mis lähtub nimede kirjutusviisidest eesti keelde tõlgitud uuskreeka autorite raamatutes (Rein 2002: 327-328).

Võib öelda, et 21. sajandil on uuskreeka nimede kasutamine eesti keeles nihkunud ajakirjanduse ning aimekirjanduse kasuks. Mõjutanud on seda Eesti astumine Euroopa Liidu liikmeks, 2004. aastal Ateenas toimunud olümpiamängud ja mõistagi viimaste aastate majanduskriis. Need sündmused on andnud põhjust kajastada kreeklasi ja kreeka nimesid nii kirjalikes tekstides kui ka suulises kõnes. 
Ei saa öelda, et eesti ja kreeka keele foneetilised süsteemid on väga erinevad (Kraut 2015: 11). Raskused tekivad pigem nimede õigekirjaga ja sellest lähtuva tähtede ja nende kombinatsioonide õige hääldusega. Uuskreeka nimede transkribeerimiseks kasutatav uuskreeka-ladina tähetabel, millest tuleks nimede kirjutamisel lähtuda, on järgnev:

Tabel 2. Uuskreeka-ladina tähetabel

\begin{tabular}{|c|c|c|c|}
\hline A a & $=a$ & $\mathrm{KK}_{\mathrm{K}}$ & $=\mathrm{k}$ \\
\hline$a u$ & $=a v$ & $\Lambda \lambda$ & $=1$ \\
\hline au & $=a f$ & $M \mu$ & $=\mathrm{m}$ \\
\hline$B \beta$ & $=\mathrm{v}$ & $\mu \pi$ & $=b$ \\
\hline$\Gamma \gamma$ & $=\mathrm{g}$ & $\mu \pi$ & $=\mathrm{mp}$ \\
\hline$\gamma Y$ & $=\mathrm{ng}$ & $\mathrm{N} v$ & $=\mathrm{n}$ \\
\hline$\gamma \xi$ & $=n x$ & $\equiv \xi$ & $=x$ \\
\hline$Y X$ & $=\mathrm{nch}$ & 00 & $=0$ \\
\hline$\Delta \delta$ & $=\mathrm{d}$ & ou & $=\mathrm{ou}$ \\
\hline$E \varepsilon$ & $=\mathrm{e}$ & П & $=p$ \\
\hline$\varepsilon U$ & $=\mathrm{ev}$ & $P \rho$ & $=r$ \\
\hline$\varepsilon U$ & $=$ ef & $\Sigma \sigma \varsigma$ & $=\mathrm{s}$ \\
\hline$Z \zeta$ & $=\mathrm{z}$ & $T_{T}$ & $=\mathrm{t}$ \\
\hline $\mathrm{H} \eta$ & $=\mathrm{i}$ & $\curlyvee u$ & $=y$ \\
\hline nu & $=\mathrm{iv}$ & $\Phi \varphi$ & $=f$ \\
\hline nu & $=$ if & $x x$ & $=\mathrm{ch}$ \\
\hline$\Theta \theta$ & $=$ th & $\Psi \psi$ & $=p s$ \\
\hline 11 & $=\mathrm{i}$ & $\Omega \omega$ & $=0$ \\
\hline
\end{tabular}

Võõrsõnades tuleb peale õigekirja ehk ortograafia esile veel üks aspekt - see on nende õige hääldus ehk ortoeepia (Sang 2016: 554). Ka uuskreeka nimedes tuleb lisaks tähtede latinisatsioonile teada tähtede ja tähekombinatsioonide hääldamise reegleid, sest transkriptsioon ei ole alati häälduspärane. Näiteks ei teata sageli, et kreeka diftong ou (ov) hääldub u-na. Tulemuseks on nimedes Farandoúri, Karaïndrou, Makrópoulos mõlema hääliku, nii o kui $u$, eraldi väljalugemine suulises kõnes, kui tuua mõned näited.

\subsection{Rõhu märkimine}

Silmatorkavaim erinevus vana- ja uuskreeka nimede transkriptsioonis on ilmselt rõhu märkimine. Liikuva rõhuga keeltes tuleks rõhku kontrollida igas uuena ettesattuvas nimes (Kraut 2015: 28). Kehtivate reeglite järgi tuleb kahe- või enamasilbilistele uuskreeka nimedele rõhk (s.o akuut) peale märkida. Vanakreeka ja bütsantsi nimedes seda ei tehta. Nagu sissejuhatuses mainitud, ei ole piir vana- ja uuskreeka nimede vahel alati selge. Rõhu märkimine puudutab kõige enam 20. ja 21. sajandi kreeka nimesid, 19. sajandi kreeka nimede latiniseeritud variantidele tavaliselt rõhku veel ei märgita. Sealgi võib õige rõhu kindlaks tegemine olla keeruline, kui siinkohal tuua näiteks 19. sajandi kreeka vabadusvõitleja nimi Theodoros 
Kolokotronis või samal sajandil elanud kreeka rahvusluuletaja nimi Dionysios Solomos.

Üldjuhul märgitaksegi uuskreeka nimedes rõhk vaid kohanimedele, ent isikunimedele jäetakse see kirjutamata. ${ }^{8}$ Kahtlemata on Kreeka kohanimede kohta infot rohkem - need on eraldi ära toodud P. Pälli raamatus "Maailma kohanimed" ja Eesti Keele Instituudi kohanimeandmebaasis (KNAB). Lisaks leidub ÕS 1999 ja ÕS 2013 uuskreeka-ladina tähetabeli illustreerimiseks toodud näidete hulgas ainult kohanimesid, mis jätab mulje, nagu kohanduksid uuskreeka nimede kirjutamiseks kehtestatud reeglid vaid neile ning mitte isikunimedele. ${ }^{9}$ Samas on uuskreeka isikunimed, eriti perekonnanimed, enamasti pikemad kui kohanimed ning vajavad rõhumärki viimastest rohkemgi. Siinkirjutaja leiab, et uuskreeka isikunimesid on raskem kirja panna, hääldada ning rõhutada kui kohanimesid. Paljud Kreeka kohanimed on aastatuhandete jooksul püsinud suuresti muutumatuna, samas kui uusi isikunimesid on rohkelt juurde tekkinud. Siinkohal võib esitada loetelu 20. ja 21. sajandi Kreeka poliitikute ja kultuuritegelaste nimedest: Kóstas Simítis, Antónis Samarás, Giánis Varoufákis, Efkleídis Tsakalótos, Prokópis Pavlópoulos, Giórgos Tzavéllas, Michális Kakogiánnis, Eléni Karaî́ndrou, Aris Messínis. Kui nendes rõhk ära jätta, ei häiri see küll kirjapildis, kuid muudab nii mõnegi nime suulise esituse raskemaks.

Vastukaaluks võib väita, et ka mõned kaasaegsemad uuskreeka nimed on eesti keeles juurdunud ja mugandunud ega vajagi rõhku. Eriti puudutab see isikunimesid, kus eesnimeks on mõni vanakreeka nimi. Võib küsida, kas kuulsa laevandusmagnaadi nime on õigem kirjutada kujul Aristoteles Onassis või Aristotélis Onásis? Ning kas tema asutatud fondi kohta peaks eesti keeles ütlema Aleksander Onassise või Aléxandros Onásis'e fond ${ }^{10}$ Mõningate (ees)nimede vanakreeka ja uuskreeka variantide vahel on erinevused üsna väikesed, nagu võib näha tabelist 3.

Tabel 3. Vanakreeka ja uuskreeka nimevariandid

\begin{tabular}{|l|l|}
\hline Vanakreeka nimekuju & Uuskreeka nimekuju \\
\hline Artemis & Artemi \\
\hline Ares & Aris \\
\hline Aristoteles & Aristotélis \\
\hline Danae & Danaí \\
\hline Eukleides & Efkleídis \\
\hline Zoe & Zoí \\
\hline Penelope & Pinilópi \\
\hline Perikles & Periklís \\
\hline Sokrates & Sokrátis \\
\hline
\end{tabular}

Kuna uuskreeka nimede puhul märgitakse rõhk tavaliselt vaid kohanimedele, siis võib välja tuua ka asjaolu, et kohanimede esinemisel tekstis ei tehta sageli vahet,

\footnotetext{
8 Siinkirjutaja on kohanud vaid üht eestikeelset kirjatööd, kus uuskreeka nimedes on rõhk märgitud nii koha- kui isikunimedele: "Metafooride tõlkimisest uuskreeka keelest Ilias Venezise "Aioolia maa" tõlke näitel” (Ulm 2011). Pealkirjas, tõsi küll, on kirjaniku nimes rõhud ära jäetud.

9 Diskussioonis Eesti Rakenduslingvistika Ühingu kevadkonverentsil 2016. aastal selgus, et selline ongi vaikiv kokkulepe. Enamasti ei ole muukeelsed kreeka nimede kasutajad suutelised isikunimedes õigele silbile rõhku

kokkulepe. Enamasti ei ole muukeelsed kreeka nimede kasutajad suutelised isikunimedes ooigele silbile röhku
märkima. Ent siiski jätab ainult kohanimedele keskendumine mulje, et kreeka isikunimedel ei tohigi rõhku olla ning seda isegi siis, kui teksti autor või tõlkija suudab selle korrektselt õigele silbile märkida. Näiteks võib siin tuua raamatud "Minu Kreeka" (Laansalu 2012) ning "Minu Kreeta" (Albri 2016), kus rõhk on vaid kohanimedel.

10 Nendel vähestel kordadel, kui see nimi on eestikeelsetes tekstides esinenud, on see kajastunud kujul Alexander S. Onassise fond, vt nt http://www.vm.ee/et/riigid/kreeka?display=relations (Välisministeerium - Kreeka).
} 
kas on tegemist kaasaegse või varasema aja kontekstiga ning kas nimi nõuab rõhumärki või mitte. Lisaks on tekstides, kus esineb uuskreeka nimesid, rõhu märkimine ebaühtlane. Näiteks võib tuua artikli Kreeta kirjanikust Nikos Kazantzakisest, kus on rõhud märgitud 19. sajandi lõpu kontekstis nimedele Irákleio ja Náxos, ent samas kirjutises esinevad muud vähemtuntud Kreeka kohanimed - Mani, Myrtia, Varvari - on jäetud ilma rõhumärgita (Rein 2007: 19). ${ }^{11}$ Kui tuua näiteid viimastel aastatel eesti keelde tõlgitud ilukirjandusest, kus esineb kreeka nimesid, siis sõltumata ajastust ja kontekstist tuntumatele kohanimedele rõhk pigem märgitakse. 2013. aastal ilmunud Ryszard Kapuściński "Reisid Herodotosega" eestinduses on rohkelt tsitaate Herodotose ajalooteosest "Historia", kus võib vanakreeka keelest tõlgitud tekstis näha akuuti nimel Kórinthos (Kapuściński 2013: 10), samas kui muud vanakreeka nimed esinevad ilma rõhumärgita. Aastal 2015 trükivalgust näinud Ugo Foscolo raamatu "Jacopo Ortise viimased kirjad” tõlke järelsõnas on 18. sajandi kontekstis rõhumärgiga esitatud nimi Zákynthos (Kolli 2015: 151). Tekib küsimus, kas see olemasolevate reeglite järgi on õige, eriti arvestades asjaolu, et raamatus rohkem kreeka nimesid ei ole ning puudub vajadus ühtlustamise järele. Seega ei tehta Kreeka kohanimede tõlgendamisel ilmtingimata vahet, millisest ajast nad pärinevad ning kas rõhu märkimise kohustust on või ei ole.

Siinkohal tekibki küsimus, kas uuskreeka nimede kirjutamisel on rõhumärgil abistav või ainult dekoratiivne funktsioon. Kahesilbilistes kreeka nimedes, kus rõhk paikneb esimesel silbil (nt Samos või Thasos), on vähe tõenäoline, et eestlane selle määramisel vääratab. Küll aga võib seda juhtuda pikemate koha- ja eriti isikunimede puhul (nt Kárpathos, Amorgós, Papadóp(o)ulos). Praegu kiputakse rõhku märkima eelkõige neile kreeka nimedele, mille rõhk on kergesti tuvastatav. Keerulisemates nimedes jäetakse see enamasti märkimata. Ent eesmärk ei tohiks olla ainult tuntumate Kreeka kohanimede korrektne kirjutamine, vaid võimalus õiget kirjutusviisi kindlaks teha ja rõhku määrata kõigis kreeka nimedes ning eriti seal, kus see on tõepoolest keeruline.

\subsection{Vahendava keele mõju nimekirjutusele}

Nagu sai eelnevates peatükkides esile toodud, on viimasel ajal inglise keelel olnud märgatav mõju kreeka nimede edasiandmisele eesti keeles. Uuskreeka nimede edasiandmise traditsioon eesti keeles on võrreldes vanakreeka, Uue Testamendi ning bütsantsi nimedega kõige lühem, seetõttu on nende puhul ka teiste keelte mõjutused kõige suuremad. Kuna maailmas toimuv jõuab meie uudistesse enamasti inglise keele vahendusel, jõuavad selle keele kaudu meieni ka kreeka nimed. Sageli võetaksegi need üksüheselt üle. Mõnede eelmises alapeatükis toodud uuskreeka isikunimede inglise keelele omased variandid on järgnevad: Costas Simitis, Yanis Varoufakis, Euclid Tsakalotos, Yorgos Javellas, Michael Cacoyannis. Ei ole haruldane, kui need jõuavad eestikeelsesse teksti samasugusel kujul.

Nendes nimekujudes võib täheldada tüüpilisi probleeme, mis kaasnevad uuskreeka nimede toomisega inglise keelest eesti keelde. Kõigepealt on nendeks tähtede $c$ ja $y$ kasutamine. Kreeka keeles $c$-häälikut ega seda tähistavat aabet ei ole, on $\kappa$ (kapa), mis peaks latiniseeritult olema $k$. Seega tuleks kreeka nimi Kóstas kirjutada $k$-ga, mitte $c$-ga. Mõnes välismaises kreeka kunstnikunimes, näiteks

11 Säärane rõhkude märkimine oli artikli toimetaja valik. 
Maria Callas, võib $c$ kindlasti alles jätta, kuid siin on tegu pigem erandiga. Omaette küsimus on mõistagi, mida teha kreeka nimedega, mis esinevad inglise või mõnes muus võõrkeeles kirjutavate autorite kirjanduslikes tekstides. Näiteks võib siin tuua vendade Durrellite raamatuis esinevad kreeka nimed Spiro, Theodores Stephanides (Durrell 1976), Capodistria, Panayotis (Durrell 2016). Neis võib täheldada nominatiivi asemel vokatiivi kasutamist, vanakreekapärase nimekuju eelistamist ning juba mainitud tähtede $c$ ja $y$ kasutamist. Valikud, kas lähtuda kirjaniku tekstist või kreeka nimede kirjutamise eestikeelsest traditsioonist, sõltuvad ilmselt tõlkijatest.

$Y$ kasutamisest oli juttu juba bütsantsi nimede peatükis ning nii vana- kui uuskreeka nimede transkriptsiooni tabelist võib näha, et selle tähega latiniseeritakse kreeka tähte $v$ (üpsilon). Inglise keele mõjutusel kasutatakse $y$-i aga hoopis $j$-i funktsioonis, mis inglise keeles on tavaline, kuid eesti keelde ei sobi. $j$-häälikule vastab uuskreeka keeles ühend $\gamma l$, mis reeglite järgi tuleks latiniseerida gi-na.

Vaatamata kreeka nimede latiniseerimise kehtivatele reeglitele tuleb tõdeda, et kreeklased ise kirjutavad ja kasutavad meelsasti oma nimesid inglise ja muude keelte tavade kohaselt, eriti puudutab see eesnimesid. Teiste keelte vahendusel eesti keelde jõudnud kreeka nimede algkuju on nii mõnigi kord raske tuvastada. Kui kreeklane ütleb inglise keeles enda nime olevat John, George või Peter, ei oska igaüks neid tagasi viia kujule Jannis, Jorgos või Petros. ${ }^{12}$ Meie ajakirjandusse on jõudnud inglise keele kaudu ka nimekuju Aristotle Onassis (Kaldoja 2006: 12), kuid selline eesnimi siiski ilmselgelt eesti keelde ei sobi. Eesti Vabariigis resideerunud Kreeka Vabariigi suursaadikud Polýdoros Kokónas ja Konstantínos Katsambís on oma nime Eestis kirjutanud vaid kujul Polydore Kokonas ja Constantine Catsambis. Tuleb möönda, et eestikeelne inimene ei pruugi osata eeltoodud nimekujusid hääldada, sest tekib küsimus, millise keele baasil seda teha. Ka mõningatel kuulsatel Kreeka või Küprose juurtega loomeinimestel on inglise või prantsuse keelele omane nimekuju, nagu näha tabelist 4 .

Tabel 4. Nimekujude varieerumine

\begin{tabular}{|l|l|}
\hline Inglise- või prantsuskeelne nimekuju & Eestikeelne vaste uuskreeka-ladina tähetabeli järgi \\
\hline Constantine Cavafy & Konstantínos Kaváfis \\
\hline George Seferis & Giórgos Seféris \\
\hline Cyprien Katsaris & Kyprianós Katsarís \\
\hline
\end{tabular}

Ilu- ja ajakirjanduses esinevate kreeka nimekujude üle saab vaielda ning neid korrigeerida. Siinkirjutajale tundub, et kreeka nimede kasutamise kõige problemaatilisem valdkond eestikeelses tekstis on diplomaatia. Selle illustratsiooniks võib tuua tabeli Eesti presidendi tegevusaruandest, kus on loetletud Kreeka poliitikud ja ametiisikud, kellele Lennart Meri andis 1999. aastal toimunud riigivisiidi ajal Valgetähe I klassi teenetemärgi.

Tabel 5. Valgetähe I klassi teenetemärgi kavalerid (Eesti tänab 1995-2001)

\begin{tabular}{|l|l|}
\hline Aristides Agathocles & Kreeka välisministeeriumi välissuhete osakonna direktor \\
\hline Constantinos Ailianos & Kreeka välisministeeriumi kantsler \\
\hline Dimitrios Avramopoulos & Ateena linnapea \\
\hline Michael Cambanis & minister, Kreeka välisministeeriumi protokolliülem \\
\hline
\end{tabular}




\begin{tabular}{|l|l|}
\hline Emmanouil Gikas & Kreeka Vabariigi Presidendi Kantselei direktor \\
\hline George Helmis & $\begin{array}{l}\text { minister, Kreeka välisministeeriumi poliitikaosakonna 1. büroo } \\
\text { direktor }\end{array}$ \\
\hline Apostolos Kaklamanis & Kreeka parlamendi president \\
\hline Merkourios Karafotias & minister, presidendi kantselei välissuhete osakonna direktor \\
\hline Yannos Kranidiotis & Kreeka asevälisminister \\
\hline George A. Papandreou & Kreeka välisminister \\
\hline Constantinos Simitis & Kreeka peaminister \\
\hline Anastasios Skopelitis & minister, Kreeka välisministeeriumi poliitikaosakonna peadirektor \\
\hline Theodoros Sotiropoulos & minister, peaministri kantselei välissuhete osakonna direktor \\
\hline Stavros Soumakis & Kreeka mereminister \\
\hline Athanassios Theodorakopoulos & minister, Kreeka Vabariigi suursaadik Eestis \\
\hline
\end{tabular}

Nimed on selles loetelus esitatud nii, nagu neid kasutatakse inglise keeles, läbisegi võib näha $c$ ja $k$ kasutamist, samuti $y$ kasutamist inglise keelele omaselt. Võimalik, et mainitud isikutel on nende diplomaatilises passis tabelis toodud latiniseeritud nimekuju ning nad eelistavad selle säilitamist. Ent sarnast nimekirjutust võib näha ka Eesti Välisministeeriumi Kreekat puudutaval kodulehel (Kreeka Vabariik üldinfo), kus kohanimede kirjapanekus on täheldatavad samasugused tendentsid. Seal võib kohata nimesid Attica ja Epirus pro Atika ning Epeiros, st eelistatud on inglisepärast varianti.

Peatüki kokkuvõtteks võib öelda, et uuskreeka nimede kasutamisel on keeruline esiteks nime kreekapärase kuju kindlaks tegemine ja selle korrektne kirjutamine ning edasi ka reeglite järgi kirjutatud nime õige häälduse ja rõhu määramine. Teised võõrkeeled, eriti inglise keel, mõjutavad nimekasutust eriti intensiivselt.

\section{Kokkuvõte}

Kreeka nimede kajastamine eestikeelses tekstis on ebaühtlane, mida on ka varasemates käsitlustes esile toodud. Suulises kõnes on sageli raske kreeka nimesid sobivalt rõhutada, sest kreeka ja eesti keele rõhureeglid erinevad. Vanakreeka nimedes tekitab segadust ka kaks rõhutamistava, kreeka ja ladina oma. Vanakreeka nimede hääldus ei tekita eestlastele palju raskusi, küll aga on probleemne uuskreeka nimede hääldamine, sest kehtivad transkriptsioonireeglid ei ole häälduspärased. Kirjalikes tekstides võib raskustena esile tuua erinevatesse ajastutesse kuuluvate kreeka nimede mitteeristamise, koha- ja isikunimede erineva kasutuse ning anglitsismide kergekäelise lubamise. Suurimaks probleemiks uuskreeka nimede jõudmisel eestikeelsetesse tekstidesse ongi nimekujude üksühene ülevõtmine inglise keelest.

Uuskreeka nimede kirjutamise ja hääldamise nõuanded on peamiselt kohanimede kohta, ent isikunimede kohta need praktiliselt puuduvad. Kohanimede jaoks on olemas eraldi andmebaas KNAB, kuid kreeka isikunimede kirjutamine ja hääldamine tekitab eesti keeles ikkagi raskusi. Tuntumate uuskreeka nimede rõhku saab kontrollida vikipeediast või mõnest kreeka nimede leksikonist (nt Lexicon of Greek Personal Names), ent seda suuresti võõrkeelte vahendusel. Seega tasuks kaaluda enamlevinud kreeka isikunimede andmebaasi loomist, kus esineksid nii 
vanakreeka, Uue Testamendi, bütsantsi kui uuskreeka nimed ning nende erinevad kasutusvariandid eesti keeles. Samuti väärib edasisist uurimist, kuidas ja millest lähtuvalt on kreeka nimesid erinevatel aegadel eesti keeles kajastatud.

\section{Viidatud kirjandus}

Albri, Jaana 2016. Minu Kreeta. Tallinn: Petrone Print.

Antiigileksikon 1983. (Tõlgitud väljaandest Lexikon der Antike 1979. Leipzig: VEB Bibliographisches Institut.) Tallinn: Valgus.

Cavallo, Guglielmo 1992. Bütsantsi inimene. Tallinn: Avita.

Durrell, Gerald 1976. Minu pere ja muud loomad. Tallinn: Eesti Raamat.

Durrell, Lawrence 2016. Justine. Tallinn: Eesti Raamat.

Kaldoja, Evelyn 2006. Athina Onassis valmistub kohtulahinguks. - Postimees 31.1, 12.

Kaplinski, Jaan 2011. Santorini. Teekond Ayia Triadasse. Tartu: Võluri tagasitulek.

Kapuściński, Ryszard 2013. Reisid Herodotosega. - Loomingu Raamatukogu, nr 13-16. Tallinn: SA Kultuurileht.

Kolli, Eva 2015. Saateks. - Ugo Foscolo, Jacopo Ortise viimased kirjad. Loomingu Raamatukogu, nr 21-23. Tallinn: SA Kultuurileht, 151-156.

Kraut, Einar 2015. Võõrnimed eesti häälduses. Praktilisi vihjeid üleüldse ja keeliti. Üldalused. Inglise keel. Vene keel. Tartu: Keelehooldekeskus.

Kurtna, Aleksander 1966. Uuskreeka nimede kirjutamisest eesti keeles. - Keel ja Kirjandus, 1,51 .

Laansalu, Ester 2012. Minu Kreeka. Tallinn: Petrone Print.

Lilleväli, Mati 200o. Piibli nimede leksikon. Tallinn: Logos.

Palli, Madis 2016. Õigeusu nimi. Tallinn: Eesti Apostlik-Õigeusu Kiriku Kirjastus.

Päll, Janika 2006. Eessõna. - Vanakreeka kirjanduse antoloogia. Tallinn: Varrak, 9-12.

Päll, Peeter 1993. Rahvusvaheline nimekorraldus ja Eesti. - Keel ja Kirjandus, 8, 465-467.

Päll, Peeter 1998. Väliskohanimede õigekiri. - Keel ja Kirjandus, 6, 411-426.

Päll, Peeter 1999. Maailma kohanimed. Tallinn: Eesti Keele Sihtasutus.

Päll, Peeter 2000. Võõrnimede häldus. - Keel ja Kirjandus, 10, 737.

Päll, Peeter 2005. Võõrnimed eestikeelses tekstis. [Foreign Names in Estonian texts.] Dissertationes philologiae estonicae Universitatis Tartuensis 15. Tartu: Tartu University Press. http://hdl.handle.net/10062/609

Rein, Kaarina 2002. Uuskreeka nimed eesti keeles. - Keel ja Kirjandus, 5, 320-328.

Rein, Kaarina 2004. Kreeklaste mängud, eestlaste tõlgendus. - Postimees 16.8, 13.

Rein, Kaarina 2007 Moodne Odysseus Nikos Kazantzakis. - Sirp 2.11, 19.

Rein, Kaarina 2016. Sõna sõnastikus ja tekstis. - Keel ja Kirjandus, 7, 571-573.

Sang, Joel 2016. Keelte kodustamisest. - Keel ja Kirjandus, 7, 553-555.

Stathakopoulos, Dionysios 2016. Bütsants. Impeeriumi ajalugu. Tallinn: Imeline ajalugu. Imeline teadus.

Ulm, Edith 2011. Metafooride tõlkimisest uuskreeka keelest Ilias Venezise "Aioolia maa" tõlke näitel. Magistritöö. Tallinna Ülikool, Germaani-Romaani Keelte ja Kultuuride Instituut, Tõlkekoolituse osakond. https://tolkelugu.wikispaces.com/file/view/ Metafooride $+\mathrm{t} \% \mathrm{C}_{3} \%$ B5lkimine.pdf (14.1.2017).

Uus Testament ja psalmid ehk Vana Testamendi laulud. Tallinn: EELK Konsistoorium, 1990. Vseviov, David 2004. Bütsantsi keisrid. Valitsejad purpuris. Tallinn: Kunst.

ÕS 1976 = Õigekeelsussõnaraamat 1976. Tallinn: Valgus.

ÕS 1999 = Eesti keele sõnaraamat ÕS 1999. Tallinn: Eesti Keele Sihtasutus.

ÕS 2013 = Eesti õigekeelsussõnaraamat 2013. Tallinn: Eesti Keele Sihtasutus. 


\section{Võrguviited}

Eesti tänab 1995-2001. https://vp1992-2001.president.ee/est/ametitegevus/Valgetaht.asp (18.9.2016).

Institute of Biblical Creek. http://www.biblicalgreek.org/links/pronunciation.php\#History (14.1.2017).

ISO 8431997 TL. https://transliteration.eki.ee/pdf/Greek.pdf (10.1.2017).

KNAB. Eesti Keele Instituudi kohanimeandmebaas. https://www.eki.ee/knab/knab.htm (12.1.2017).

Kreeka Vabariik - üldinfo. http://www.vm.ee/et/kreeka-vabariik-uldinfo (12.1.2017).

Lexicon of Greek Personal Names. http://www.lgpn.ox.ac.uk/index.html (14.1.2017).

Methis. Studia humaniora Estonica. http://www.methis.ee/et (14.1.2017).

Piibel.net. http://piibel.net/ (12.1.2017).

Vana- ja uuskreeka-ladina tähetabel. http://www.eki.ee/knab/trkr kreeka.pdf (12.1.2017).

Välisministeerium - Kreeka. http://www.vm.ee/et/riigid/kreeka?display=relations (14.1.2017).

Kaarina Rein (Tartu Ülikool) on õppinud klassikalist filoloogiat, tõlkinud vana- ja uuskreeka keelest eesti keelde, uurinud kreeka keele ja kirjanduse retseptsiooni Eestis ning varauusaegseid meditsiinitekste.

W. Struve 1, 50091 Tartu, Estonia

kaarina.rein@ut.ee 


\title{
GREEK NAMES IN ESTONIAN WRITTEN AND ORAL LANGUAGE
}

\author{
Kaarina Rein \\ University of Tartu
}

The issue of how to write Greek names in Estonian has been a recurring topic in Estonia. It is not always easy to follow the transcription rules, as there is often no information on how the Greek names are actually written in Greek. Greek names are transported into Estonian mostly from other languages and thus also traditions and pronunciation rules of other languages are admitted into Estonian. Most often, such influences now originate from English.

There have been different ways and traditions of rendering Ancient Greek, New Testament, Byzantine and Modern Greek names in Estonian. Rules for transcription of Greek names in Estonian are established only for Ancient and Modern Greek names. However, it is not always easy to perceive differences even between these names and their use in Estonian. Questions arise as to which rules should be used while writing e.g. Greek geographical names which have been used in antiquity and are still in use today. In addition, Modern Greek personal names and place names are rendered differently in Estonian. Moreover, problems of stress and pronunciation are sometimes difficult to solve in oral speech.

The article gives a survey of the use of Greek names in Estonian written texts and oral language at the end of the 2oth and in the 21st century and highlights problems in the use of these names.

Keywords: Greek names, Ancient Greek names, Modern Greek names, onomastics, language contacts 